9 Основи охорони праці: підручник / К.Н. Ткачук, М.О. Халімовський, В.В. Зацарний [та ін.]. - 2-ге вид. - Харків: Основа, 2006. - 448 с.

10 Аналіз стану виробничого травматизму та умов праці на підприємствах транспортно-дорожнього комплексу та галузі поштового зв'язку за 2014 [Електронний ресурс]. - Режим доступу: piкhttps://mtu. gov.ua/files/analiz_avar_2014.pdf.

11 Дикань В. Л. Забезпечення ефективності інноваційної діяльності підприємств залізничного транспорту: монографія / В. Л. Дикань, В. О. Зубенко. - Х.- УкрДАЗТ, 2008. - 194 с.
12 Козодой Д.С. Вимоги до сучасної системи управління охороною праці підприємств залізничного транспорту / Д.С. Козодой // Весник ХНАДУ, вып. 59, 2012. - с. 95 - 99.

13 Сусленко В. Необхідно створити єдину корпоративну систему управління охороною праці в ПАТ «Укрзалізниця» [Електронний ресурс] / В. Сусленко. Режим доступу: http://ukrrailways.com/ intervyu/1783-valerij-suslenko-neobkhidnostvoriti-edinu-korpo rativnu-sistemuupravlinnya-okhoronoyu-pratsi-dlya-patukrzaliznitsya.html

\title{
АКТУАЛЬНІСТЬ ВПРОВАДЖЕННЯ ЛОГІСТИЧНИХ СИСТЕМ НА ТРАНСПОРТНИХ ПІДПРИЕМСТВАХ ДЛЯ ЗАБЕЗПЕЧЕННЯ ЇХ КОНКУРЕНТОСПРОМОЖНОСТІ
}

\author{
Устенко М.О., к.е.н., доцент, \\ Івачкевич В.С., магістр (УкрДУЗТ)
}

У статті розглянуто питання інтеграції логістичної системи в процес управління підприємствами транспорту та ї̈ впливу на конкурентоспроможність. Визначено, щзо підвищення ефективності інтегрованої логістичної системи є одним з основних чинників забезпечення конкурентних переваг підприємства. Проведено дослідження впливу макрологістичних систем на функиіонування мікрологістичних систем, на основі якого побудовано механізм впливу ключових компетенцій логістики у забезпеченні конкурентоспроможності підприємства, який запропоновано розуміти як процес прийняття управлінських рішень щуодо закупівлі, виробництва, збуту за умови інтеграції ключових компетениій логістики з урахуванням впливу внутрішнього та зовнішнього середовища у загальній стратегії підприємства, щзо дозволяє використовувати сучасні технології логістичного менеджменту з метою забезпечення ефективності інтегрованої логістичної системи та високого рівня конкурентоспроможності підприємства.

Ключові слова: логістика, логістична система, логістичний підхід, інтеграція, конкурентоспроможність, підприємство, транспорт

(C) Устенко М.O., Івашкевич В.C.
Вісник економіки транспорту і промисловості № 60, 2017 


\title{
АКТУАЛЬНОСТЬ ВНЕДРЕНИЯ ЛОГИСТИЧЕСКИХ СИСТЕМ НА ТРАНСПОРТНЫХ ПРЕДПРИЯТИЯХ ДЛЯ ОБЕСПЕЧЕНИЯ ИХ КОНКУРЕНТОСПОСОБНОСТИ
}

\author{
Устенко М.А., к.э.н., доцент, \\ Ивачкевич В.С., магистр (УкрГУЖТ)
}

\begin{abstract}
В статье рассмотрены вопросы интеграции логистической системы в процесс управления предприятиями транспорта и ее влияния на конкурентоспособность. Определено, что повышение эффективности интегрированной логистической системы является одним из основных факторов обеспечения конкурентных преимуществ предприятия. Проведено исследование влияния макрологистических систем на функиионирование микрологистических систем, на основе которого построен механизм влияния ключевых компетенций логистики в обеспечении конкурентоспособности предприятия, который предложено рассматривать как процесс принятия управленческих решений по закупке, производству, сбыту при условии интеграции ключевых компетенций логистики с учетом влияния внутренней и внешней среды в общей стратегии предприятия, что позволяет использовать современные технологии логистического менеджмента с целью обеспечения эффрективности интегрированной логистической системы и высокого уровня конкурентоспособности предприятия.
\end{abstract}

Ключевые слова: логистика, логистическая система, логистический подход, интеграция, конкурентоспособность, предприятие, транспорт

\section{ACTUALITY OF LOGISTIC SYSTEMS IMPLEMENTATION IN TRANSPORT ENTERPRISES TO PROTECT THEIR COMPETITIVENESS}

\author{
Ustenko M.O., Candidate of Economic Sciences, \\ Ivashkevych V.S., magister (USU of RT)
}

The article considers logistics system integration in process of management transport enterprises and their impact on competitiveness. It is determined, that increase of efficiency of the integrated logistic system is one of the main factors of providing of competitive advantages of the enterprise.The study of the influence of macro-logistic systems on the functioning of micro-logistic systems, on the basis of which the mechanism of influence of the key competences of logistics in ensuring the competitiveness of the enterprise is constructed, which is proposed to be understood as the process of making managerial decisions on procurement, production and sales, provided that the integration of key competencies of logistics is integrated, taking into account the influence of internal and external environment in the general strategy of the enterprise, which allows using modern technologies logistically management to ensure the effectiveness of the integrated logistics system and a high level of competitiveness.

Key words: logistics, transport and logistic system, logistic approach, integration, competitiveness, enterprise, transport

Вісник економіки транспорту і промисловості № 60, 2017 
Постановка проблеми. Існуюча конкуренція на ринку транспортних послуг, вимагає все нових підходів до розвитку транспортних відносин, створення нових технологій та підвищення якості послуг. Виходячи 3 сучасних особливостей розвитку ринкових відносин, найбільш сталі конкурентні позиції мають ті підприємства, які, окрім традиційних шляхів забезпечення власної конкурентоспроможності, використовують ще й нетрадиційні шляхи отримання конкурентних переваг. Одним 3 таких шляхів $€$ супроводження продукції підприємств пакетом додаткових послуг.

Оскільки конкурентні переваги, що забезпечені такими факторами як ціна, реклама, якість, швидкість доставки товару на ринок та інші, є легко повторюваними, робота із забезпечення стійкої конкурентоспроможності підприємства як на внутрішньому, так і на міжнародному ринках повинна проводитися на тлі диференціації пакету послуг, що супроводжують продукт 3 моменту його проектування до післяпродажного обслуговування.

\section{Диференціація}

супроводжувальних продукцію послуг проявляється у намаганні інтегрувати функції закупок, виробництва та збуту при прийнятті управлінських рішень. На даний час функцію диференціації пакету додаткових послуг, що супроводжують продукт, виконує логістика. При цьому логістика виступає прикладною стратегією концентрації управління, що об’єднує між собою час і простір, а також виконує вище зазначені функції [3].

Аналіз останніх досліджень i публікацій. Дослідження функціонування логістичних систем висвітлюється у працях багатьох вчених. Зокрема, слід виокремити наступних 3 них: Григорьев М. Н. [1], Сухорукова Т.Г. [5], Єлагін Ю.В. [6], Зборовська О. М. [7], Крикавський Є. В. [8], Миротин Л. Б. [9], Скоробогатова Т. Н.
[10]. У їх працях сформульовано основні засади формування та функціонування логістичних систем, їх інтеграції в управління підприємством.

Вплив впровадження логістичних систем на забезпечення конкурентоспроможності підприємства висвітлено у працях багатьох вчених, серед яких, зокрема, слід виділити дослідження Диканя В.Л. [3], [4] та Данько М.I. [2].

Виділення невирішених частин загальної проблеми. Разом 3 тим аналіз публікацій свідчить, що недостатньо уваги приділялося саме обгрунтуванню необхідності впровадження логістичних систем на транспортних підприємствах для підвищення їх конкурентоспроможності в галузі.

Метою статті $\epsilon$ дослідження теоретичних питань щодо впровадження логістичних систем та їх впливу на конкурентоспроможність підприємства

Виклад основного матеріалу дослідження. На практиці застосовуються логістичні системи двох типів: макрологістичні та мікрологістичні.

Макрологістична система $є$ великою логістичною систему управління потоковими процесами за участю декількох i більше незалежних суб'єктів господарювання, не обмежених у територіальному розташовувані. Виділяють такі макрологістичні системи: регіональні, національні (міжрегіональні) та міжнаціональні.

Створення макрологістичних систем обумовлене необхідністю забезпечити чітку взаємодію різногалузевих структур з метою поліпшення економічного стану на глобальному рівні. Під час створення макрологістичних систем особливу увагу приділяють взаємопогодженню інтересів кожного учасника незалежно від його ролі у створеній системі.

Цілі створення макрологістичних систем можуть значною мірою відрізнятися від цілей i критеріїв синтезу

Вісник економіки транспорту і промисловості № 60, 2017 
мікрологістичних систем. У більшості випадків критерій мінімуму загальних логістичних витрат використовується і під час синтезу макрологістичних систем. Однак найчастіше критерії формування макрологістичних систем визначаються екологічними, соціальними, військовими, політичними та іншими цілями[2].

Наприклад, для поліпшення екологічної ситуації в регіоні може бути створена макрологістична система оптимізації транспортних (вантажних) регіональних потоків, що вирішує задачі:

- оптимізації маршруті;

- розв'язання транспортних потоків;

- переключення 3 одного виду транспорту на інший.

3 погляду державних органів управління, які також можуть брати участь у створенні макрологістичної системи, позитивний ефект може виражатися, наприклад, у поліпшенні загальної економічної ситуації в регіоні, країні або між державами. Таким чином, макрологістична система $\epsilon$ високо інтегрованою інфраструктурою економіки регіону, країни або групи країн.

Мікрологістична система охоплює внутрішньовиробничу логістичну сферу одного підприємства або групи підприємств, об'єднаних на корпоративних засадах. До мікрологістичної системи належать технологічно пов'язані виробництва, об'єднані єдиною інфраструктурою, які працюють на єдиний економічний результат. Мікрологістичну систему підприємства можна подати у вигляді основних підсистем: закупівлі, виробництва і збуту.

Закупівля - підсистема, яка забезпечує надходження матеріального потоку в логістичну систему.

Планування та управління виробництвом - ця підсистема приймає матеріальний потік від підсистеми закупівель та управляє ним в процесі виконання різних технологічних операцій, які перетворюють предмет праці в продукт праці. Збут - підсистема, яка забезпечує вибуття матеріального потоку з логістичної системи.

Елементи логістичних систем різноякісні, але одночасно сумісні. Сумісність елементів забезпечується єдністю цілі, якій підпорядковане функціонування кожного 3 елементів логістичної системи. Також в економічній літературі зустрічається думка, що мікрологістичні системи $€$ окремими ланками макрологістичних систем. Однак це не завжди так. Виробничо-господарські структури, які входять у макрологістичну систему і $є$ юридично незалежними, можуть виконувати усі вимоги i функції даної системи, сприймаючи їх як фактор зовнішнього середовища. При цьому свою внутрішньовиробничу i господарську діяльність вони можуть здійснювати традиційно.

3 іншого боку, підприємство, яке функціонує на основі логістичної концепції, може не входити в макрологістичну систему, тим більше якщо іiі немає. Воно будує свою діяльність як локальна мікрологістична система, що адаптується до динамічного зовнішнього середовища. Таким чином, макрологістична система являє собою велике логістичне утворення декількох незалежних суб'єктів господарювання, не обмежених у територіальному розташуванні.

Мікрологістична система, у свою чергу, охоплює внутрішньовиробничу логістичну сферу одного підприємства або групи підприємств, об'єднаних на корпоративних засадах. При цьому слід зазначити, що напрямок розвитку макрологістичної системи відображається на функціонуванні мікрологістичної системи через процеси адаптації підприємств до змін зовнішнього середовища.

На основі дослідження сучасних особливостей впровадження логістичних

Вісник економіки транспорту і промисловості № 60, 2017 
технологій у діяльність підприємств 3 урахуванням процесів розвитку прикордонних територій i визначення організаційної структури, що здатна поєднати зусилля промисловості та транспорту в напрямку підвищення конкурентоспроможності, сформовано принципи, на яких повинно будуватися застосування логістичних технологій:

- моніторинг ринку виробництва i збуту, а також залучення вантажів до перевезення транспортною системою України;

- побудова ланцюга від виробника до споживача за участю всіх видів транспорту (перш за все, залізничного як стратегічного об'єкту економіки України); здійснення логістичного управління процесом перевезень;

- відповідальність за реалізацію логістичного ланцюга на усьому шляху переміщення вантажів;

- організація єдиного митного простору сусідніх прикордонних регіонів;

- дослідження ринку напрямків та обсягів прикордонного співробітництва, визначення основних вантажів, що у великих обсягах перевозяться через кордон, та удосконалення організації їх перевезення;

забезпечення взаємодії прикордонних регіонів сусідніх країн у науково-технічному співробітництві [5].

Спрямована на досягнення високої якості обслуговування споживачів, логістична система підприємства будується на засадах інтеграції ключових компетенцій логістики, що дозволяе використовувати сучасні технології логістичного менеджменту з метою досягнення високого рівня конкурентоспроможності підприємства (рис. 1).

Підвищення

ефективності інтегрованої логістичної системи досягається за рахунок успіхів у сфері впливу кожної ключової компетенції логістики. При чому успіх у сфері впливу ключової компетенції логістики вважається успіхом лише у тому випадку, якщо він безпосередньо впливає на підвищення загальної ефективності інтегрованої логістичної системи [4].

Підвищення ефективності

інтегрованої логістичної системи є одним 3 основних чинників підвищення конкурентоспроможності підприємства. За даними Європейської асоціації логістики застосування сучасних технологій логістичного менеджменту дозволяє скоротити час виробництва продукції на $25 \%$, знизити собівартість виробництва продукції до $30 \%$, скоротити обсяг матеріально-технічних запасів від 30\% до $70 \%$ [7].

У світовій практиці спостерігається наступне розподілення загального часу надходження продукції у промисловологістичному обороті:

- 3\% часу - у виробництві;

- $10 \%$ часу - у процесі

транспортування (перевезення);

- 87\% часу - у процесі додаткової обробки, пакування (склад).

Саме тому виробники продукції намагаються скоротити накопичені запаси через інтеграцію корпоративних i оперативних функцій у логістику.

У цілому розвиток логістики спрямований на подолання просторового розриву. Проте з розвитком промисловості у результаті науково-технічного прогресу логістичне обслуговування значно змінилося від впливом внутрішньої та зовнішньої конкуренції. За останні часи впровадження логістичних систем у діяльність підприємств було спрямовано на управління виробництвом, транспортуванням, збереженням і запасами. На початку ж використання логістики в управлінні підприємством впровадження логістичних систем, переважно, було спрямовано на управління каналами просування продукції на споживчі ринки.

Вісник економіки транспорту і промисловості № 60, 2017 


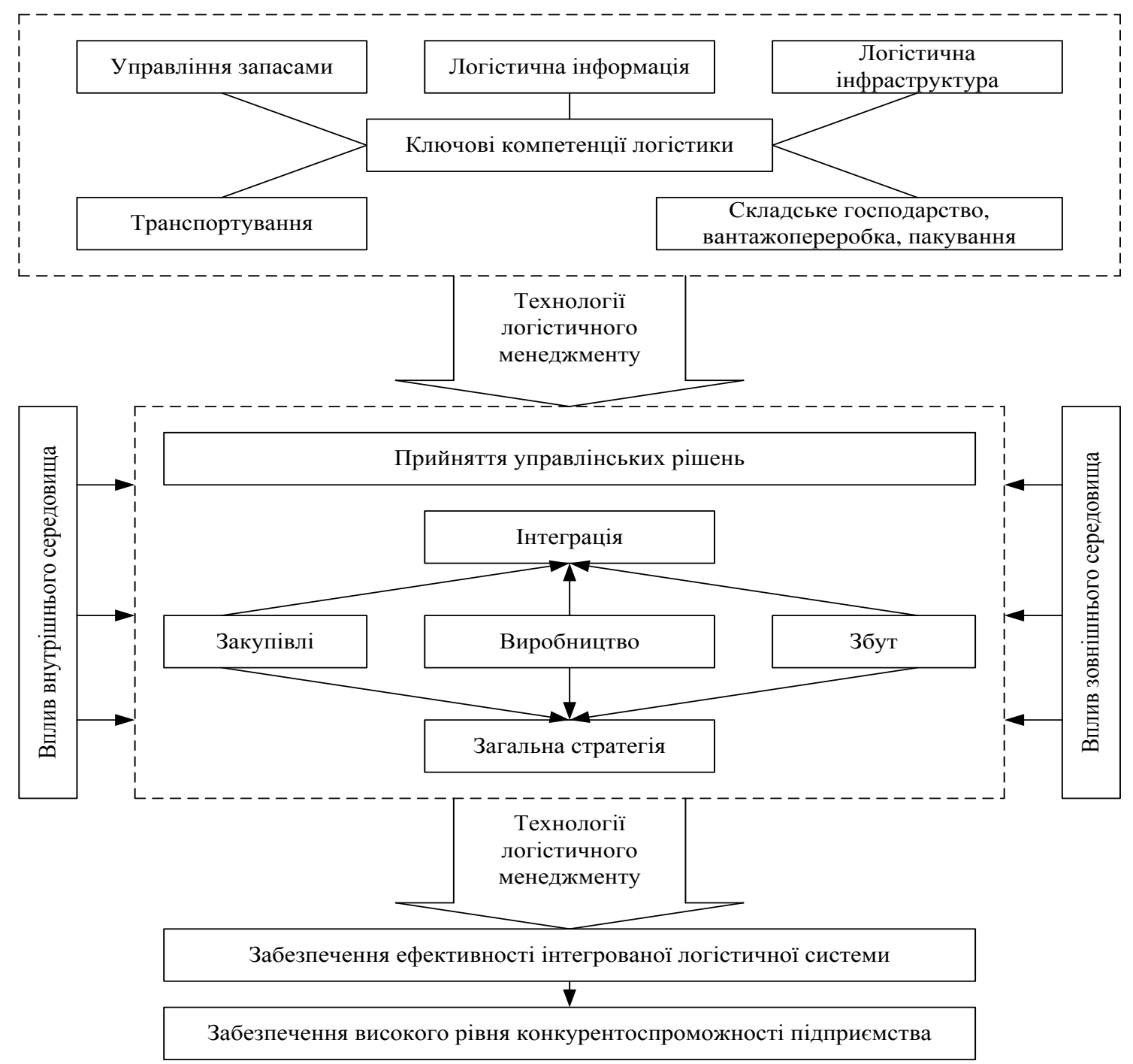

Рис. 1. Механізм впливу ключових компетенцій логістики у забезпеченні конкурентоспроможності підприємства

Сучасні логістичні системи, ефективність, як і зростання обсягу збуту побудовані на застосуванні провідних на 10\% (компанії «Дженерал Моторс», інформаційних технологій, дозволяють не тільки не відставати від конкурентів, але й випереджати їх. Серед результатів впровадження логістичних систем 3 використанням інформаційних технологій Всесвітнім банком за аналізом діяльності 1450 компаній США, Канади, Японії та семи західноєвропейських країн було зафіксовано досягнення конкурентних переваг [6]: «Бош», «Сіменс», «Мітсубісі»);

- управління каналами просування продукції призводить до скорочення тривалості циклу замовлення на $80 \%$ i розміру запасів на $30-70 \%$, підвищенню продуктивності на 20-50\%, зменшенню витрат на доставку продукції до $30 \%$ (Свропейська асоціація промисловості);

- організація отримання товарів за допомогою електронних замовлень - зниження на $1 \%$ витрат на дозволила багатьом компаніям підвищити логістику таким чином впливає на обсяг збуту до 50\% (Асоціація

Вісник економіки транспорту і промисловості № 60, 2017 
промисловості США);

- у результаті удосконалення

логістики та скорочення запасів на $30 \%$ зменшилися витрати на збереження та капітальні вкладення, що, у свою чергу, призвело до зростання прибутку на активи майже на $35 \%$ (Хенкель інтернешнл кемікалс);

- використовуючи інтегроване управління логістикою, деякі промислові компанії знизили до $25 \%$ тривалість процесу виробництва продукції, що дозволило їм скоротити на 20\% загальні витрати на маркетинг (Бостон консалтинг груп).

Висновок. Таким чином, впровадження логістики у діяльність підприємства та формування його логістичної системи дозволить:

- гармонізувати внутрішні бізнеспроцеси підприємства, підвищити ефективність діяльності його функціональних підрозділів;

- скоротити витрати та зменшити собівартість продукції;

- збільшити кількість потенційних і фактичних споживачів, утримати та розширити ринок збуту;

- підвищити конкурентоспроможність підприємства в умовах жорсткої конкуренції.

\section{ПЕРЕЛІК ВИКОРИСТАНИХ ДЖЕРЕЛ}

1. Григорьев М. Н. Логистика: учеб. пособие [для студентов вузов] / М.Н. Грирогьев, А.П. Долгов, С.А. Уваров. М.: Гардарики, 2006. - 463 с.

2. Данько M.I. Забезпечення конкурентоспроможності національної мережі міжнародних транспортних коридорів: Монографія/ Данько М.I., Дикань В.Л., Толстова А.В. - Харків.: УкрДАЗТ, 2013 - 188c.

3. Дикань В.Л. Забезпечення конкурентоспроможності підприємств:
Підручник / Дикань В.Л., Боровик Ю.Т., Полякова О.М., Уткіна Ю.М. - Харків: УкрДАЗТ, $2012-415 \mathrm{c}$.

4. Дикань В.Л. Глобализационные процессы в экономике Украины/ В.Л.Дикань, А.В. Козуб// Вісник економіки транспорту і промисловості. - 2017.- № 58. C.9-18

5. Сухорукова Т.Г. Характеристика класифікаційних ознак транспортної логістики [Текст] / Т.Г.Сухорукова // Вісник економіки транспорту i промисловості: зб. наук. пр. - Х.: УкрДАЗТ, 2014. - № 47. - C.51-57.

6. Єлагин Ю.В. Сутність та роль логістичних підходів в підвищенні ефективності обслуговування пасажирів [Текст] / Ю.В. Слагин // Вісник економіки транспорту і промисловості: зб. наук. пр. Х.: УкрДАЗТ, 2013. - № 44. - С.44-46.

7. Зборовська О. М. Особливості проектування i розвитку логістичних систем у промисловості [Текст] / О. М. Зборовська // Бюлетень Міжнародного Нобелівського економічного форуму. 2010. - №1(3). - Том 2. - С. 132-136.

8. Крикавський Є. В. Логістичні системи: навчальний посібник [Текст]/ Є. В. Крикавський, Н. В. Чорнописька. Львів: Видавництво Національного університету «Львівська політехніка», 2009. $-246 \mathrm{c}$.

9. Миротин Л. Б. Логистика: учебное пособие [Текст] / Л. Б. Миротин, В. И. Сергеев. - М.: ИНФРА-М, 2000. - 200 c.

10. Скоробогатова Т. Н. Логистика: учебное пособие [Текст]

Т. Н. Скоробогатова. - $[2-\mathrm{e}$ изд.]. Симферополь, Омега-Л, 2009. - 256 с.

11. Устенко М. О. Організаційноекономічні підходи щодо створення логістичної системи прикордонного регіону : автореф. дис. канд. екон. наук: 08.00.03 / М. О. Устенко; Укр. держ. акад. залізн. трансп. - Х., 2013. - 23 с.

Вісник економіки транспорту і промисловості № 60, 2017 